\title{
OVERHEAD COSTS AND PROFIT CALCULATION BY POLISH CONTRACTORS
}

\author{
Edyta PLEBANKIEWICZ, Agnieszka LEŚNIAK \\ Section of Technology and Building Management, Cracow University of Technology, \\ Warszawska 24, 31-155 Kraków, Poland
}

Received 20 December 2010; accepted 27 October 2011

\begin{abstract}
The main criterion taken into consideration when choosing a contractor is the bid price that the contractor suggests. The basis for determining such a price are the direct costs connected with works realization as well as mark-ups, mainly overhead costs and profit. Overhead costs and profit constitute a considerable part of the bid price and their improper calculation can significantly influence the financial situation of the company. In literature and in practice one can find many definitions and ways of determining overhead costs and profit. The article presents research results concerning defining and calculating overhead costs and profit by Polish contractors, carried out twice - in 2004 and 2010. They were compared with similar studies performed in other countries. The article also presents mathematical methods created by the authors, by means of which overhead costs and profit can be calculated more precisely than by the popular methods commonly employed by Polish contractors.
\end{abstract}

Keywords: direct costs, mark-ups, overhead costs, profit.

Reference to this paper should be made as follows: Plebankiewicz, E.; Leśniak, A. 2013. Overhead costs and profit calculation by Polish contractors, Technological and Economic Development of Economy 19(1): 141-161.

JEL Classification: C45, D24, L11, L74.

\section{Introduction}

When choosing a contractor, the owner presents a number of conditions to be fulfilled. $\mathrm{Nu}$ merous methods that allow to check the contactors' competence in detail have been worked out, which consequently increase the chance to choose the best tenderer (Singh, Tiong 2005; Waara, Brochner 2006; Elazouni 2006; Mitkus, Trinkūnienè 2007; Zavadskas et al. 2008;

Corresponding address:

E. Plebankiewicz E-mail: eplebank@izwbit.pk.edu.pl 
Brauers et al. 2008; Mitkus, Trinkūnienè 2008; Plebankiewicz 2009; Zavadskas et al. 2010). However, it should be noted that the main factor taken into consideration when choosing a contractor is the bid price (Turskis 2008; Mitkus, Trinkūnienè 2008).

To be competitive, the contractor tendering for the contract should pay special attention to calculating the price for which he/she is willing to complete the particular works. To determine the price he/she should consider the direct costs connected with realization of the works, which are directly dependent on the scope of such works (labour costs, costs of the materials and equipment, costs of means of technological transport), as well as mark-ups, i.e. mainly overhead costs and profit. The influence of improper calculation of the overhead costs and profit can be significant for the financial situation of the company. Too high an estimation causes inflation of cost calculation, which may not be accepted by the owner. Too low an evaluation can cause that the contractor will suffer losses when realizing given works.

In literature and in practice one can find different definitions and ways of determining overhead costs and profit. The legal regulations being in effect in Poland till 2001 to a great degree imposed the ways of cost calculating, including overheads and profit. Changes that followed in recent years (Kapliński 2008; 2009), also influenced the methods of calculating the bid price.

The paper aims at presenting the results of studies concerning the methods of defining and calculating overheads and profit by Polish contractors and comparing them with similar studies carried out in other countries. The paper also presents mathematical methods created by the authors, by means of which overhead costs and profit can be calculated more precisely than by the popular methods commonly employed by Polish contractors.

\section{Defining overhead costs and profit}

In literature and in practice one can find different definitions of overhead costs (Cilensek 1991; Tah et al. 1994; Holland, Hobson 1999; Assaf et al. 2001; Adey et al. 2004; Enshassi et al. 2008; Šiškina et al. 2009; Apanaviciene, Daugeliene 2011). It is worth noting that some contractors cannot precisely define this notion. A research carried out in the USA revealed that over $60 \%$ of the contractors responding to the survey cannot adequately determine the definition of overhead costs (Holland, Hobson 1999).

Generally, an overhead cost can be defined as a cost that cannot be identified with or charged to a construction project or to a unit of construction production. Another definition describes overhead costs as those that are not a component of the actual construction work but are incurred by the contractor to support the work (Cilensek 1991). In his work Tebin (2009) enumerates nine basic elements that should be taken into account in overhead costs:

1) employer's requirements (accommodations - office, toilets, telephone, equipment);

2) management and staff (site manager, general foreman);

3) facilities and services (power/lighting/heating, water, telephone);

4) temporary works (access route, hard standings, dewatering);

5) site accommodations (offices, stores, canteen, drying and first aid room);

6) attendant labour (unloading and distribution, cleaning, setting and assistants); 
7) contract conditions (fluctuations, insurances, bonds);

8) non-mechanical plant;

9) miscellaneous (setting out consumables, testing and samples, seasonal working).

Generally, the contractor's overhead costs are divided into two categories: project overhead costs and company's (also called general) overhead costs. Project overhead costs include items that can be identified with a particular job, but are not materials, labour, or production equipment. Company's overhead costs are items that represent the cost of doing business and often are considered as fixed expenses that must be paid by the contractor.

Polish Standards of Construction Works Cost Estimating (Polskie standardy... 2005), being a model study concerning cost calculations and being used by Polish owners and contractors, define two main components of overhead costs and precisely determine their content:

1) project overhead costs;

2) company's overhead costs.

Project overhead costs can be defined as all the costs incurred by the contractor on the building site in connection with the works realization, excluded from the standard costs of labour and materials together with the costs of their purchase, and the costs of building equipment. The following costs are included:

1) payments and mark-ups on the regular construction staff;

2) wear out costs of temporary construction base;

3) wear out costs of light equipment and tools;

4) health and safety at work costs;

5) additional costs of employing commuting staff;

6) other general construction costs (energy consumption, media, telephones, all small materials and wearing out equipment).

Company's overhead costs cover the costs of functioning units and work stations of the staff working in general administration, performing supervising, inspection, recording and reporting and briefing functions, as well as jobs connected with organizing and managing the construction company. Company's overhead costs include:

1) payments and mark-ups of management staff;

2) business trip costs;

3) exploitation costs of company cars;

4) office costs and costs of general purpose buildings maintenance;

5) financial costs;

6) other management costs (e.g. social fund maintenance costs, legal advice, outside expert opinions, management staff health and safety costs).

Kosecki and Leśniak (2001) present results of the research carried out in Poland, which concerned determining the influence of particular elements of overhead costs on their height. To carry out the research the authors used a questionnaire sent by post to construction companies. The questionnaire was sent to a hundred construction companies chosen at random. Nineteen companies answered it. The results show that payments and payment mark-ups of regular construction staff have the greatest influence on the height of project overhead costs 
while the remaining costs remain the least influential. Another additional component pointed out by the contractors and considered to be vital is the costs connected with occupying the pavements and streets, in this way causing traffic restrictions. Company's overhead costs are, in turn, mostly influenced by payment costs and overheads of the management staff and the least influence is caused by such costs as e.g. legal advice, outside experts opinions, or health and safety costs concerning management staff. Additionally, the respondents mentioned the representative costs of the company.

Profit is one more element that considerably influences the financial situation of a construction company. Generally, profit is a surplus of an income over the incurred costs. For a construction company profit is an indispensable earning allowing it to function and develop. Profit, calculated in cost estimation, is a forecasting of this earning. It has to be high enough to allow the contractor, in case of winning a tender, a decent earning and yet low enough to make a bid offer competitive in getting the order. Profit is determined by the contractor on the level indispensable to be able to finance future expenses and loses, as well as allowing the company to function and develop properly. Profit, as any calculated element of the estimation costs, is of prognostic character. It determines the planned or foreseen amount, thus it can be different from the actual amount which is known only after having realized and calculated the works.

It must be noted that there are differences in understanding the elements of the estimation costs in Poland and in other countries. In English speaking countries there is a term "margin" or "mark-up". They both include profit and usually a part of overhead costs. These are mainly company's overhead costs. In some cases risk is also included (in Poland it is included in the profit).

Hegazy and Moselhi (1995) presented the results of the research into calculating construction costs in Canada and the United States. The authors carried out a survey sending questionnaires to 427 contractors in both countries altogether. Ninety contractors answered the questionnaire, which was $21 \%$ of all the questionnaires. The researchers took into consideration only 78 questionnaires which fulfilled the given demands. The survey shows that there is latitude in interpreting the notion of mark-up. Here American and Canadian contractors include different elements:

1) profit;

2) incidental expenses (contingency);

3) project overhead costs;

4) company's overhead costs.

Contingency is an amount connected with possible expenses not included in tender documentation. It is treated as a kind of buffer to level the influence of costs increase. This amount does not always need to be taken into consideration when estimating costs.

Mark-up as a profit has been defined by $44 \%$ of contractors taking part in the survey. Additionally, contingency is included in mark-up by $33 \%$. For $17 \%$ of the contractors mark-up is a profit and company's overheads, for $4 \%$ - profit, company's overheads and contingency and for the remaining $2 \%$ - profit, company's overheads, project overheads and contingency. 


\section{Methods of determining overhead costs and profit}

In the work mentioned above (Hegazy, Moselhi 1995) the authors presented methods of calculating overhead costs by contractors in Canada and the USA. The overwhelming majority of those questioned (83\%) enumerate project overhead costs in detail, while only $14 \%$ uses index method assuming the value of direct costs as a basis.

The most often used method when calculating a company's overhead costs is to calculate the value of these costs in percentages from a given basis. $31 \%$ of those questioned show that the basis is the value of direct costs, $27 \%$ assume the sum of direct and project overhead costs as a basis. $18 \%$ of the companies taking part in the questionnaire calculate in detail the future value of a company's overhead costs. What is worth notifying is the fact that as many as $19 \%$ do not calculate this element of costs separately but mention its value when calculating mark-up.

Studies have also shown that contractors determine mark-up sum in different ways.

The method of company's overhead costs calculation is to calculate them in percentages from a given basis. Mark-up from all costs (direct and overhead costs) is calculated by $40 \%$ of contractors, $27 \%$ from direct and project overhead costs, and 33\% only from direct costs. It can be noticed that the way of defining mark-up is strictly connected with the way it is calculated in. For example, $44 \%$ of the respondents consider mark-up as a profit only and about $40 \%$ calculate mark-up from direct and overhead costs.

Legal acts in effect in Poland since 2001 precisely regulate the principles of making cost calculations by Polish construction contractors, bid price mark-up calculation included. Traditionally, making use of these as well as previous principles, it has become customary that contractors determine overhead costs as percentage index from labour and equipment, and profit as percentage index from labour, equipment and overhead costs. Such a point of view often did not reflect the actual costs and profit generated by the contractor, especially when the indexes used were not differentiated. The consequences were often disadvantageous - inflating other price elements, problems with completing the project connected with giving unrealistically low bid price, and the like.

On 12 December 2001 a new act came into force - an act about prices of 5 July 2001 (Act Record nr 97, position 1050), which does not introduce any detailed regulations about construction costs determination. In agreement with its content, in reference to construction work prices article 2, para. 1 is in effect "Prices of goods and services are agreed upon by the sides signing the contract". Thus, since 2001 the contractor is free to quote cost calculations, being limited only by the owner's guidelines for a given order. The idea behind the changes introduced in 2001 was to make the contractor use realistic prices at which he is actually able to execute the order.

\section{The method of carrying out the research and respondents' characteristics}

In order to learn about the ways of determining mark-ups in practice, the authors of the paper carried out a survey among Polish contractors twice. The first pilot ones were carried out in April 2004 among twelve contractors. The questionnaire used during interviews with 
company representatives had three parts. The first one allowed to form a short characteristics of a company. In the second and third ones the questions concerned aspects of overhead costs and profit calculations interesting for the authors.

The companies taking part in the questionnaire were characterized on the basis of information about the number of people employed, kind of activity and the region they work in. According to data received, $25 \%$ of the companies employed fewer than fifty people, $33 \%$ of the companies employed up to 100 people, two companies (17\%) employed up to 400 people, $25 \%$ of the questioned companies employed more than 400 . Majority indicated more than one kind of activity. Most often mentioned were public buildings ( $83 \%$ of the respondents and residential and industrial buildings (equally $75 \%$ of the respondents). Engineering works, as well as monument conservation were also mentioned. $25 \%$ of the companies were active internationally, $33 \%$ nationally and $42 \%$ were active only regionally.

The next survey, including 58 companies, was carried out in the first half of 2010 . The aim was not only to learn about the rules and methods of overhead cost calculation but also to know whether a ten-year-period of new principles of cost calculation functioning influenced a different method of cost calculation by the contractors. The questionnaire, similarly as the one from 2004, consisted of three parts.

Companies taking part in the questionnaire were again characterized on the basis of information about the number of people employed, kind of activity and the region they are active in. In agreement with the European Commission Order nr 364 from 25 February 2004, the companies can be divided depending on the number of people employed into small (employment up to 49 people), average (50-250 people) and big ones (above 250 people). Taking this criterion into consideration just under half of the companies taking part in the research were small ones ( $45 \%$ ), $24 \%$ were average and $31 \%$ big. Majority of those questioned indicated more than one kind of activity. The most often mentioned scope of activity was: public building $-69 \%$ of the respondents, and residential building $-51 \%$ of the respondents. Engineering structures were mentioned by $38 \%$ of the respondents. Also installations, industrial apparatus and technological industrial installations were mentioned. Most of the companies are active on the national market $-62 \%, 28 \%$ on the local market (Małopolskie region, Silesia) and only $10 \%$ on the international market.

\section{Estimating overhead costs by Polish contractors}

Graphic illustrations of the results concerning the methods of overhead cost estimation by the contractors questioned in 2004 are presented in Figs 1 and 2.

Graphic illustrations of the results concerning the methods of overhead cost estimation by the contractors questioned in 2010 are presented in Figs 3 and 4 . 


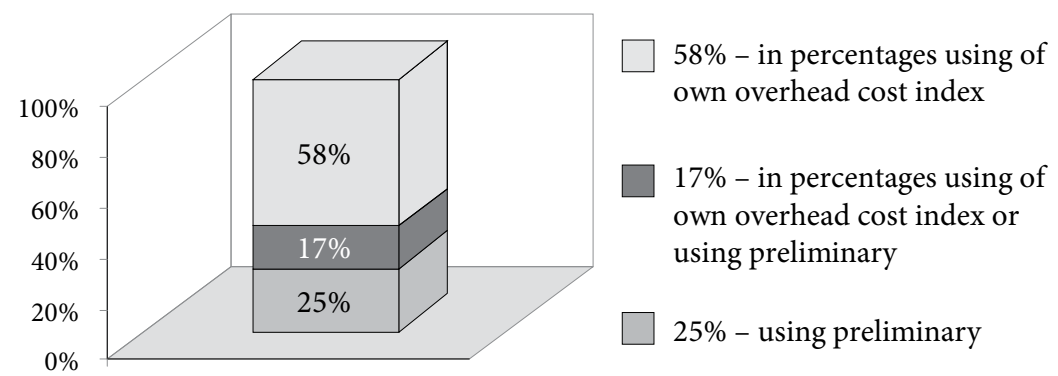

Fig. 1. Overhead cost calculation methods (2004)

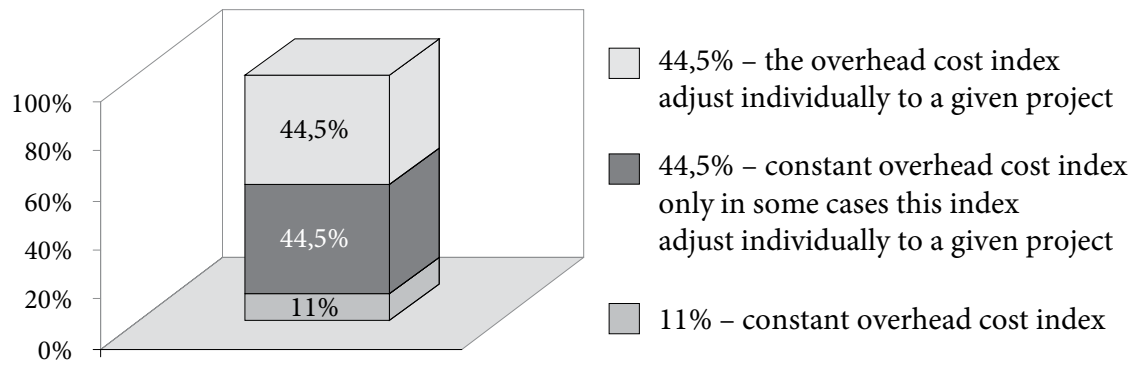

Fig. 2. The kind of index accepted in case of overhead cost determination by index method (2004)

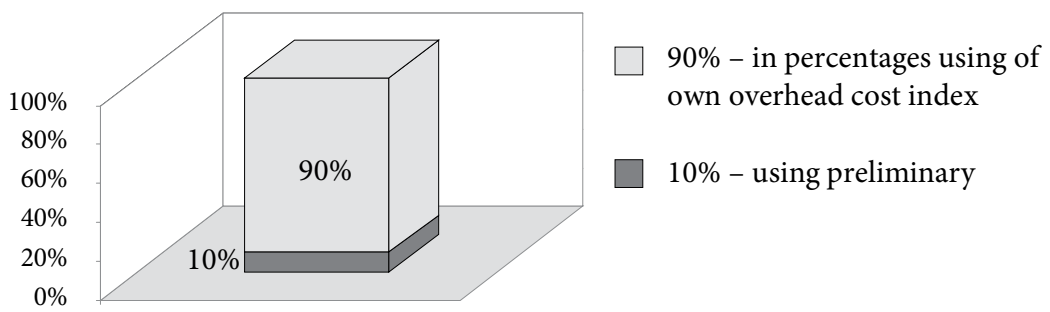

Fig. 3. Overhead cost calculation methods (2010)

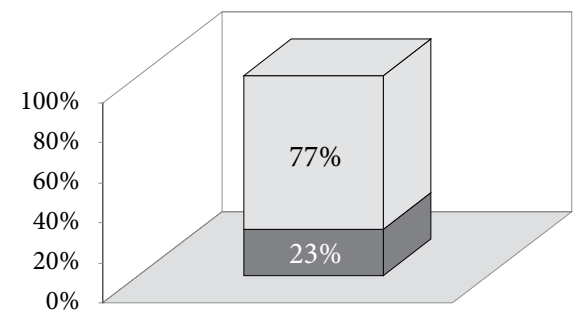

$77 \%$ - the overhead cost index adjust individually to a given project

$23 \%$ - constant overhead cost index only in some cases this index adjust individually to a given project

Fig. 4.The kind of index accepted in case of overhead costs (2010) 


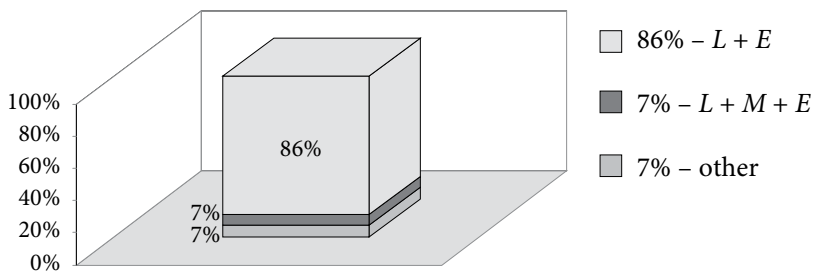

Fig. 5. Bases of calculating overhead costs (2010)

Fig. 5 shows basis accepted by the contractors to determine overhead costs.

From the results of 2010 survey it is visible that most of the contractors determine their overhead costs by index method (90\%). Only $10 \%$ of those questioned determine overhead costs in detail, using so called preliminary. All contractors using index method make use of their own overhead cost index. In the answers collected there was no published index mentioned. Most contractors (77\%) adjust the overhead cost index individually to a given project. The next $23 \%$ accept the same index, no matter what kind of project it is, and only in some cases (projects especially important for the company) determine this index individually. No contractor accepts a constant overhead cost index, no matter what the specificity of a given project is.

A majority (86\%) of the contractors takes overhead cost determining the sum of labour $(L)$ and equipment $(E)$ usage costs as the basis. $7 \%$ of the respondents indicated taking into account the sum of labour $(L)$, materials $(M)$ and equipment $(E)$ usage costs, the remaining $7 \%$ indicated other bases, such as entered overhead costs and their own calculations.

In comparison with results from 2004 it may be alarming that the contractors to a lesser degree make use of the preliminary of the overhead costs (in $2004-25 \%$, in $2010-10 \%$ ). A detailed calculation of the overhead costs is the most precise method and is widely used in other countries (Waara, Brochner 2006). It may, however, be assumed that answers - "own calculations", referring to the bases of overhead costs calculating, may be a certain form of detailed calculations. Contractors to a greater degree adjust overhead costs index to a given project - in 2004 only $45 \%$ of the respondents adjusted overhead costs index to a project, in 2010 it was already $77 \%$. None of the contractors used the same index in all the projects.

It must also be noticed that there is a greater differentiation in the assumed bases of overhead costs calculations. In 2004 only one contractor declared using a different basis than labour and equipment usage calculating, in 2010 it was $14 \%$. The changes, in comparison to research carried out in 2004, may prove that the contractors have been looking for the most profitable and the most realistic forms of overhead costs calculations.

\section{Estimating profit by Polish construction contractors}

The results of the research on different methods of determining profit by Polish construction contractors obtained in 2004 are illustrated graphically in Figs 6 and 7.

The results of the research concerning methods of profit determination by Polish construction contractors obtained in 2010 are graphically illustrated in Fig. 8.

Accepted bases of profit calculation in 2010 are shown in Fig. 9. 


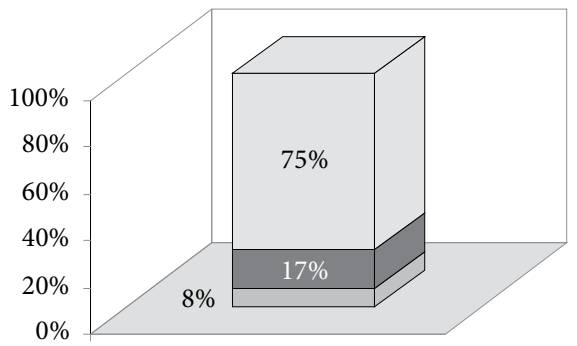

$75 \%$ - in percentages using of own index

$17 \%$ - in percentages using of own index or settled amount of money

$8 \%$ - settled amount of money

Fig. 6. Methods of determining profit (2004)

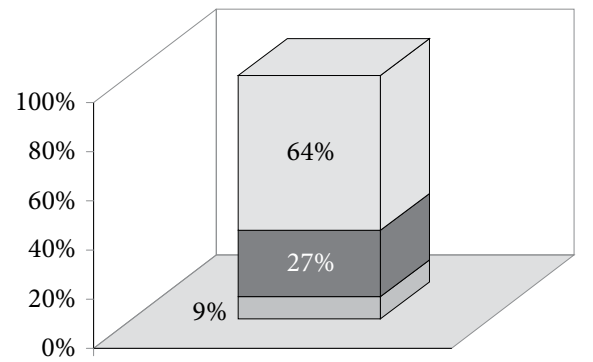

$64 \%$ - the index

adjust individually to a given project

$27 \%$ - constant index

only in some cases this index

adjust individually to a given project

$9 \%$ - constant index

Fig. 7. The kind of index accepted in case of determining profit in percentage (2004)

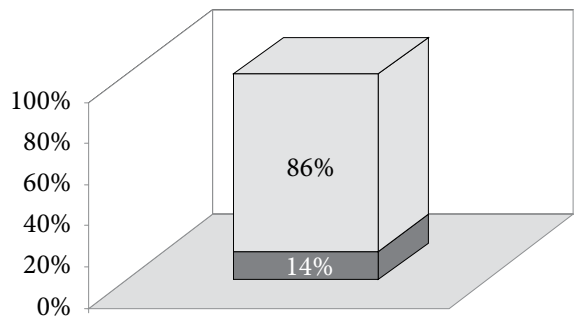

$86 \%$ - the index

adjust individually to a given project

$14 \%$ - constant index

only in some cases this index

adjust individually to a given project

Fig. 8. The kind of accepted profit index (2010)

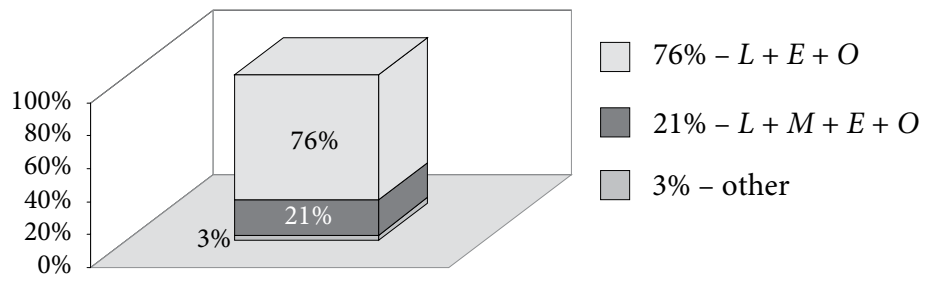

Fig. 9. Bases of profit calculation (2010) 
All those questioned in 2010 declared determining profit by index method, which suggests that none of the contractors used any other method e.g. accepting a settled amount of money. All survey participants use their own profit index, most of them (86\%) adjusting it individually to a given project. No contractor treats it as a constant index for all the projects.

Most of those questioned (76\%) accept profit determination work costs as the basis, that is labour $(L)$, equipment $(E)$ running and overhead costs $(O) .21 \%$ of the companies indicated costs of production, that is labour $(L)$, material $(M)$, equipment $(E)$ and overhead costs $(O), 3 \%$ indicated a different basis, taking into consideration also additional subcontraction costs.

In comparison to 2004 results it can be noticed that more contractors adjust profit index individually to a given project (in 2004 only $64 \%$ did this, in $2010-86 \%$ ). There is also a greater differentiation in the bases accepted for profit calculation. In $2004-84 \%$ traditionally accepted work costs as the basis.

\section{Other mark-ups used by Polish contractors}

In the survey carried out in 2010 the contractors were also asked about other mark-ups which they take into account when calculating costs. As many as $10 \%$ of the respondents indicated "purchase costs" here. It is a mark-up typical of Polish calculation costs which was used on the force of law till 2010 and was connected with building materials transportation from the purchase place to the building site. Since 2001 it is recommended that purchase costs should be included in the building materials costs. As the survey results show a large group of contractors calculates purchase costs in a traditional way, accepting them as a mark-up.

Other mark-ups mentioned by the respondents are: a cost of rent equipment, subcontraction costs, main contractor financial service costs - that is percent for running the construction for the main contractor - containers, insurance, manager. One of the respondents indicated that he also takes into account other mark-ups but he cannot reveal them as it is a commercial secret. A considerable majority of contractors declared that they always added overhead costs and profit. Just one of the respondents declared that he takes overheads into account only in some projects and another one stated that although he always takes overhead into account, their values may be zero.

\section{Mathematical methods of overhead costs calculating}

Polish contractors calculate the value of overhead costs by means of one of the following methods: the indicator-based method or the preliminary-estimate-based one. The indicator-based method is simpler, however, it does not take into consideration the particular conditions of realization and specificity of the given works. Its considerable drawback is low precision in estimating costs, especially when the published index is used. The preliminary estimate method of overhead costs calculation involves preparing detailed preliminary estimates for all elements of overhead costs. This allows to eliminate the drawbacks of the indicative method mentioned above, yet it requires a lot of time and effort. Therefore, there 
is a need of finding a new way of calculating overhead costs which would employ both the simplicity and swiftness of the indicative method and the particular conditions of the realization of the planned works.

An attempt to determine the overhead costs index by means of artificial neural networks is presented below (Leśniak 2004).

In order to prepare a method of determining the overhead costs index employing artificial neural networks an appropriate database had to be developed. Thus research was carried out in a number of selected building companies. Quantitative studies into the factors influencing overhead costs of building works were done and the actual costs of completing the works which the companies incur were calculated. As a result, a database of 72 building projects was obtained.

The proposed model taking the form of an artificial neural network aims at estimating a method of calculating overhead costs basing on the overheads index which includes the particular conditions of works realization. The value of the index was the output parameter of the network. The variables describing the shaping of overhead costs were the input parameters.

Following the research presented in detail by Leśniak (2002), seven factors constituting input parameters of the model neural network were adopted:

$x_{1}$ - type of works;

$x_{2}$ - complexity of the project;

$x_{3}$ - project duration;

$x_{4}$ - location of the building site;

$x_{5}$ - distance between the building site and the company's seat;

$x_{6}$ - realization the project in winter;

$x_{7}$ - costs of subcontractors.

Basing on the actual values of overhead costs incurred as a result of completing projects, the overhead costs index was estimated based on the following formula:

$$
W_{K_{p}}=\frac{K_{p}}{X},
$$

where $W_{K_{p}}$ - overhead costs index; $K_{p}$ - overhead costs; $X$ - the adopted basis of overhead costs calculation.

As the basis of calculating the index the sum of the costs of labour, equipment, means of technological transport and the costs of subcontractors $\left(L+E+C_{\text {sub }}\right)$ was adopted.

The attempt to solve the problem being investigated here was conducted as follows:

When designing the structure of the model network the simplest form of the network was adopted with one hidden layer.

Figure 10 presents a schema of the obtained two-layer network with a 7-3-1 structure.

The task in question involved a set of data consisting of 72 samples. It was assumed that the learning set was made of 50 randomly selected samples $(L=50)$ while the testing set included the remaining 22 samples $(T=22)$. The attempt to solve the task using artificial neural networks involved the usage of three learning algorithms: back propagation, Levenberg-Marquardt and conjugate gradients $(C G)$. A detailed description of algorithms can be found in many works on neural networks (Ossowski 2000). For the neurons of the hidden layer the authors assumed a binary sigmoid function of activation and a linear one for the output neuron. 


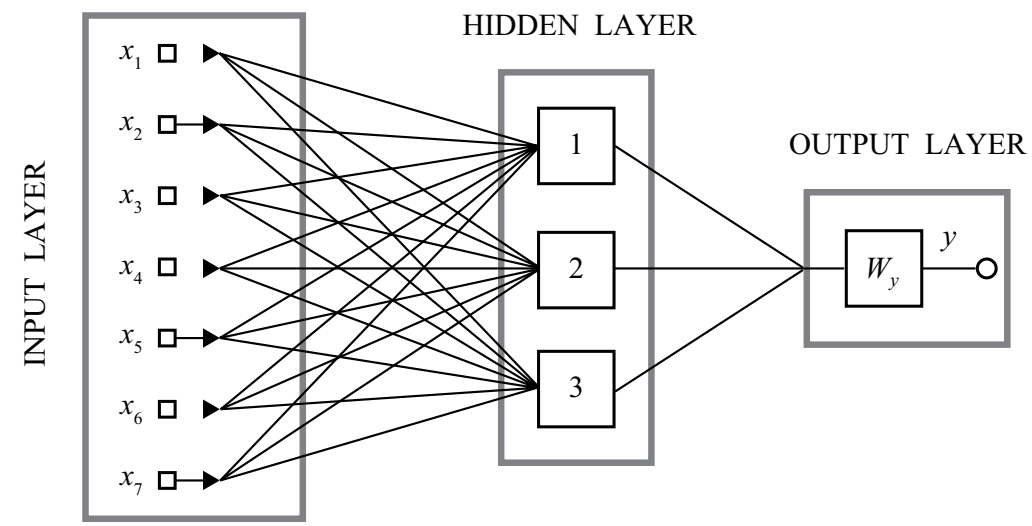

Fig. 10. Structure of the model network

As a criterion for the fitting of the network between the network's answer and the predicted values, the authors adopted the Root Mean Squared Error (RMSE) estimated for the learning set (RMSL) and the testing set (RMST) according to the following formula:

$$
R M S E=\sqrt{\frac{1}{P}\left(\sum_{p=1}^{P} \sum_{i=1}^{M}\left(t_{i}^{(p)}-y_{i}^{(p)}\right)^{2}\right)},
$$

where $p$ - number of the sample; $i$ - number of the output layer neuron; $t_{i}$ - known values of the costs indices being tested; $y_{i}$ - calculated values of the costs indices being tested.

Two criteria for the termination of the learning process were employed:

1) the criterion of the number of epochs $s_{e q}$ for which the learning and testing errors are approximately equal $(R M S L \approx R M S T)$;

2 ) the criterion of the number of epochs $s_{\text {min }}$ for which the testing error is minimal.

For network learning the first neuron to be used was the backpropagation algorithm $(B P)$, assuming the momentum of $a=0.2$ and the learning constant of $\mathrm{h}=0.6 .20$ random selections of the learning set $(L=50)$ from among the whole set of data was done and the remaining samples were left as the testing set $(T=22)$. For each selection learning and testing of the network was performed. The results obtained (the maximal, minimal and average error RMS for 20 selections) are presented in Table 1. The divergence of the results (minimal and maximal values of the RMSL and RMST errors) was judged as too broad, thus unsatisfactory. Then an attempt of network learning was undertaken using the Levenberg-Marquardt algorithm and the conjugate gradients method. They were employed for the above-mentioned 20 selections of the learning set, which were used for learning with the $B P$ algorithm. The structure of the network remained unchanged. The results of the learning process (maximal, minimal and average $R M S$ error for 20 selections) are presented in Table 1 too. 
Table 1. Results of learning and testing of the neural network $B P-W_{K P}$ (200 epochs)

\begin{tabular}{|c|c|c|c|c|c|c|}
\hline \multirow{3}{*}{$\begin{array}{l}\text { For } 20 \text { selections } \\
\text { of the learning set: }\end{array}$} & \multirow{2}{*}{\multicolumn{2}{|c|}{$\begin{array}{c}\text { Back Propagation } \\
\text { Algorithm } \\
(200 \text { epochs })\end{array}$}} & \multicolumn{2}{|c|}{$\begin{array}{c}\text { Levenberg-Marquardt } \\
\text { Algorithm } \\
\text { (50 epochs) } \\
\end{array}$} & \multicolumn{2}{|c|}{$\begin{array}{l}\text { Conjugate gradients } \\
\text { Algorithm } \\
\text { (100 epochs) }\end{array}$} \\
\hline & & & \multicolumn{2}{|c|}{$R M S$ error for sets: } & \multicolumn{2}{|c|}{$R M S$ error for sets: } \\
\hline & $L=50$ & $T=22$ & $L=50$ & $T=22$ & $L=50$ & $T=22$ \\
\hline maximal error & 0.2279 & 0.2272 & 0.1438 & 0.1446 & 0.1462 & 0.1488 \\
\hline minimal error & 0.1354 & 0.1349 & 0.1259 & 0.1208 & 0.1087 & 0.1188 \\
\hline average error & 0.1624 & 0.1608 & 0.1354 & 0.1360 & 0.1334 & 0.1365 \\
\hline
\end{tabular}

The analysis of the values presented in Table 1, especially of the average error RMS for the testing set, revealed that the best results were obtained by the Levenberg-Marquardt $(L M)$ algorithm. Therefore, a comparison of the results of learning and testing of the network with a varying number of neurons in the hidden layer was performed. First 4 and then 5 neurons were admitted. The results obtained (maximal, minimal and average $R M S$ error) are presented in Table 2. As a comparison, the results for the network structure with three neurons in the hidden layer are provided.

Table 2. Results of learning and testing of the neural network $L M-W_{K P}$ with a varying structure (50 epochs)

\begin{tabular}{|c|c|c|c|c|c|c|}
\hline & \multicolumn{6}{|c|}{ Network structure } \\
\hline & \multicolumn{2}{|c|}{$7-3-1$} & \multicolumn{2}{|c|}{$7-4-1$} & \multicolumn{2}{|c|}{$7-5-1$} \\
\hline \multirow{2}{*}{$\begin{array}{l}\text { For } 20 \text { selections } \\
\text { of the learning set: }\end{array}$} & \multicolumn{2}{|c|}{$R M S$ error for sets: } & \multicolumn{2}{|c|}{$R M S$ error for sets: } & \multicolumn{2}{|c|}{$R M S$ error for sets: } \\
\hline & $L$ & $T$ & $L$ & $T$ & $L$ & $T$ \\
\hline maximal error & 0.1438 & 0.1446 & 0.1439 & 0.1641 & 0.1441 & 0.1715 \\
\hline minimal error & 0.1259 & 0.1208 & 0.1251 & 0.1284 & 0.1257 & 0.1234 \\
\hline average error & 0.1351 & 0.1350 & 0.1350 & 0.1405 & 0.1353 & 0.1415 \\
\hline
\end{tabular}

On the basis of the received average values of the $R M S$ error for the testing set (basing on the average values of the RMST error) the authors concluded that the best results were obtained for the network of the 7-3-1 structure. Therefore, the existing 20 selections of the learning set from the whole set of data were complemented with another 80 random selections. The results attained (maximal, minimal and average $R M S$ error for 100 selections) are given in Table 3.

Table 3. Results of learning and testing of the neural network $L M-W_{K P}$ (50 epochs)

\begin{tabular}{lcc}
\hline & \multicolumn{2}{c}{$R M S$ error for sets: } \\
\cline { 2 - 3 } For 100 selections of the learning set: & $L$ & $T$ \\
\hline maximal error & 0.1476 & 0.1498 \\
\hline minimal error & 0.1214 & 0.1208 \\
\hline average error & 0.1362 & 0.1369 \\
\hline
\end{tabular}


For the subsequent analysis (also for the comparison of the results) from among 100 selections already done the authors chose a selection the results of which ( $R M S L=0,1359$ and $R M S T=0,1358)$ approximate the average values of $R M S$ errors for the learning and testing sets of all the selections.

The results of the estimation of the overhead costs for the 72 projects being investigated, which was based on the overhead costs index specified by the artificial neural network, were compared with the results obtained by means of the published index. The value of the index was adopted according to Polish price information "Sekocenbud". Overhead costs were calculated according to the following formula:

$$
K_{p}=W_{K_{p}} \cdot X,
$$

where $K_{p}$ - overhead costs; $W_{K_{p}}$ - overhead costs index; $X$ - the basis of overhead costs calculation: $\left(L+E+C_{\text {sub }}\right)$ - for the index specified by SSN; $(L+E)$ - for the published index.

The comparison of the estimation precision was performed based on the costs relative error. The results are provided in Table 4.

Table 4. Relative error of overhead costs for the projects investigated

\begin{tabular}{lcc}
\hline \multirow{2}{*}{ Name } & \multicolumn{2}{c}{ Value of the error } \\
\cline { 2 - 3 } & $\begin{array}{c}\text { for costs prognosis } \\
\text { according to SSN index }\end{array}$ & $\begin{array}{c}\text { for costs prognosis according } \\
\text { to published index }\end{array}$ \\
\hline Average relative error of the index & $31 \%$ & $52 \%$ \\
\hline Maximal relative error of the index & $122 \%$ & $167 \%$ \\
\hline
\end{tabular}

Employing the overhead costs index specified by the SSN model increased the precision of the overhead costs prognosis in comparison with the index method used so far, which is based on the published index. The results of the comparison of the two methods suggest that the proposed method can be used in practice.

\section{Mathematical methods of profit specifying}

In stabilized economy, with high competition, the contractors fight to win contracts, to a great extent, by the height of the mark-up rate they hold. The importance of estimating mark-up properly can be proved by the fact that in literature decisions about participating in a tender and about the mark-up introduced to the bid offer were shortly called bid decisions. Bid decisions are generally considered to be complex and difficult, at the same time they considerably influence the situation of the company. Mistakes made here may cause increasing difficulties of the company, bankruptcy including. In taking a decision one must consider numerous factors, in many cases not easily measurable. Therefore attempts at establishing a procedure which would facilitate this.

First attempts at working out such a procedure that would be helpful in determining the most proper mark-up in a given situation were made in the fifties of the $20^{\text {th }}$ century. A pioneer work discussing the problem is the article written in 1956 by Friedman. 
Friedman's (1956) main strategic problem is to determine the probability of winning a bid as a mark-up function, simultaneously maximizing the expected mark-up. Some time later numerous models were created, which made use of different types of mathematical theories (Chua et al. 2001; Fayek 1998; Skitmore 2004; Skitmore et al. 2001; Li, Love 1999; Chua, Li 2000; Dikmen et al. 2007; Dulaimi, Hong 2002; Egemen, Mohamed 2008; Han, Diekmann 2001; Hosny, Elhakeem 2012).

On the basis of the fuzzy sets theory, the model created by Fayek (1998) and the authors' research into the factors influencing Polish contractors' bidding decisions, including Polish experiences of settling calls for bids, the authors prepared a model of a bidding strategy whose schema is presented below (Plebankiewicz 2001).

Let us assume that you want to bid for a building contract and you wish to specify the level of the calculated profit which would be the best in the given conditions.

Let us assume the following procedure:

1. You specify the bracket of the calculated profit by providing its minimal $(x)$ and maximal $(y)$ value. The values are defined on the basis of an individual evaluation of a given bidding situation, the current market condition, etc.

You divide the calculated profit into 5 brackets. This particular division was chosen because it has been proved that distinguishing between more than 6 profit values is difficult. The values of the calculated profit $Z_{k}$ is set according to the following formula:

$$
Z_{k}=[x+(p-1) z] \% \text { for } p=1 \text { to } 6,
$$

where $z=(y-x) / 5$.

2. You identify the objectives $O_{i}$ which are the contractor's goal in a given bidding. Each objective is assigned "weight" $\left(W_{j}\right)$, i.e. the degree to which the contractor is striving to achieve the goal. The set of objectives is thus a fuzzy set and $W_{j}$ symbolizes the degree of affiliation to the set. $W_{j}$ is specified within the range from $0(0 \%)$ for "insignificant" to $1(100 \%)$ for "of greatest significance". The contractor uses a $0-100$ scale which ensures very high precision. Yet for the sake of fuzzy sets it is essential to transform this scale into a $0-1$ one.

The models used so far have taken into consideration only one bidding objective - winning the bid. However, it often happens that it is not the only and the most important objective. The bidding objectives which the contractor is willing to achieve are connected with the situation within the company - the need for work, availability of means, etc. - and with external factors influencing a company - competition, etc. The objectives can also be influenced by certain factors connected with the nature of the project which the given bidding concerns - location, the strategic value of the project, etc.

In general, the model accounts for the following objectives which the contractor wants to achieve in the bidding process:

1) winning the bid $\left(O_{1}\right)$;

2) maximizing profits $\left(\mathrm{O}_{2}\right)$;

3) testing the market $\left(\mathrm{O}_{3}\right)$;

4) minimizing the profit of competitors $\left(\mathrm{O}_{4}\right)$;

$5)$ minimizing the predicted losses $\left(O_{5}\right)$. 
3. You identify factors $F_{n}$ which influence the decision about the height of the calculated profit and specify the degree of their adjustment to the expectations of the contractor $A_{n}$ (on the scale $0(0 \%)$ if you dislike them, or $1(100 \%)$ if they are the most preferable). Correspondingly to the sets of objectives, you deal here with a fuzzy set, the elements of which are factors and $A_{n}$ symbolizes the degree of their affiliation to the set.

4. You identify the degree $\left(I_{j n}\right)$ to which factor $F_{n}$ influences objective $O_{j}$, and the value of the calculated profit which is the best for the given pair objective - factor.

5. You calculate the elements $S(O, F)$ using the following formula:

$$
S\left(O_{j}, F_{n}\right)=S_{j n}=W_{j} \cdot A_{n} \cdot I_{j n} \cdot
$$

$S(O, F)$ is a fuzzy relation, which specifies the relationship between factor $\mathrm{F}$ and objective $O$.

6. You assign elements $R(F, Z)$, where $R(F, Z)$ is a fuzzy relation specifying the relationship between factor $F$ and profit $Z$.

7. You assign elements $Q(O, Z)$ which are a composition of two fuzzy relations $S(O, F)$ and $R(F, Z)$, and which specify the dependency between objective $O$ and calculated profit $Z$ through their relationship with factor $F$.

The composition of the relations is assigned according to the max-min and sum-min rule.

The composition of the max-min relation for data $O_{j}$ i $Z_{p}$ is specified by:

$$
S \text { o } R\left(O_{j}, Z_{p}\right)=\max \min \left[S\left(O_{j}, F_{n}\right), R\left(F_{n}, Z_{p}\right)\right] \text { for every } F_{n} \text {. }
$$

For any value of the calculated profit $Z_{p}$ the general force with which it is recommended is calculated according to the following formula:

$$
Q\left(O, Z_{p}\right)=\left[S Q\left(O_{j}, Z_{p}\right)\right] / S W_{j} \text { for } j=1 \text { to } 2 .
$$

The composition of the sum-min relation for data $O_{j}$ and $Z_{p}$ is specified by:

$$
S \text { o } R\left(O_{j}, Z_{p}\right)=\operatorname{sum} \min \left[S\left(O_{j}, F_{n}\right), \mathrm{R}\left(F_{n}, Z_{p}\right)\right] \text { for every } F_{n} \text {. }
$$

For any value of the calculated profit $Z_{p}$ the general force with which it is recommended is calculated according to the following formula:

$$
Q\left(O, Z_{p}\right)=\left[S Q\left(O_{j}, Z_{p}\right)\right] / S W_{j} \text { for } j=1 \text { to } 2 .
$$

In the next stage the force with which the given calculated profit in a bid is recommended to be used is corrected because of the introduction of two additional elements:

1) the importance which the orderer attaches to the price provided in the bid;

2) the index of the percentage of those bidding settlements in which the offer with the lowest bid price won.

Theoretically, it can be assumed that if the orderer, while evaluating a bid, specifies importance of $0 \%$ for the price criterion, you can introduce a maximal value of the calculated profit, i.e. $Z_{6}$ to the bidding offer (the price for the orderer is immaterial, so the highest value can be given freely). On the other hand, if the orderer gives the price criterion the highest value, i.e. $100 \%$, the lowest value of the calculated profit, i.e. $Z_{1}$, should best be provided (if price is 
of such considerable importance, your chances will be the greatest when you give the lowest value of the calculated profit). The intermediate values of price importance correspond to the relevant values of the calculated profit. These dependencies are illustrated by Figure 11.

Assuming that $B_{x}$ is the importance which the orderer attaches to the price criterion in a given bid, the dependence between $B_{x}$ and the value of calcualted profit $Z_{y}$ can be described as follows:

$$
Z_{y}=\left(Z_{1}-Z_{6}\right) B_{x}+Z_{6}
$$

The value of calculated profit $Z_{y}$ obtained in this way is the most advantageous for the contractor from the point of view of the importance which the orderer attaches to the price criterion when evaluating bids. To this value coefficient 1.0 is ascribed and to the other values of calculated profit - coefficients reduced by 0.2 respectively. In this way you receive a corrected degree of recommendation as to the introduction of calculated profit $Z_{p}$, specified as $Q_{K}\left(Z_{p}\right)$, to the bid.

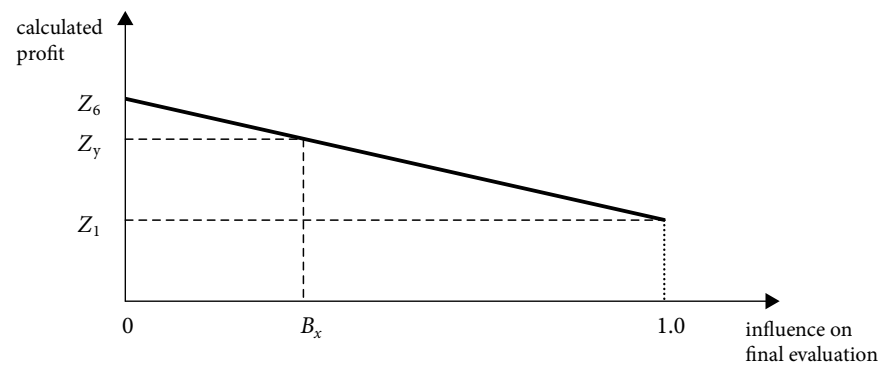

Fig. 11. Graphical interpretation of Bx coefficient

You specify the index of the percentage of those bidding processes in which the winning bid offered the minimal price, i.e. $C_{x}$. This can be either the last year's index or the average one from a couple of previous years. For the lowest price (the lowest calculated profit, $Z_{1}$ ) coefficient $C_{x}$ is assumed. For the highest price (the highest calculated profit, $Z_{6}$ ) coefficient 1.00 is adopted, and for the other values of calculated profit - coefficients changing proportionally.

A general description is as follows:

Let $Q_{o}\left(Z_{p}\right)$ indicate the final degree of recommendation of introducing calculated profit $Z_{p}$ to the bid. Then:

$$
Q_{O}\left(Z_{p}\right)=\left\{Q_{K}\left(Z_{p}\right) \cdot\left[C_{x}+g \cdot(p-1)\right]\right\}
$$

where $g=\frac{1-C_{x}}{5}$.

The model of such a bidding strategy is illustrated by the following schema.

It must be noticed that overhead costs and profit have a considerable share in cost calculations. According to research (Tah et al. 1994), in case of residential building the average share of these elements is about $17 \%$ of the total calculation cost $(12 \%$ - overhead costs, $5 \%$ - profit). Therefore it is worth paying attention to calculating these values. 


\section{A schema of a model of the bidding strategy}

\section{Data:}

1. $Z_{\min }, Z_{\max }$ - bracket of the calculated profit

2. $O_{j}$ - contractor's objectives in a given bid and

$W_{j}$ - degree in which the contractor attempts to reach a given objective

3. $F_{n}$ - factors influencing the decision of the height of the calculated profit and

$A_{n}$ - degree of adjustment of the factors to the contractor's expectations

4. $I_{j n}$ - degree of influence of factor $F_{n}$ on objective $O_{j}$

5. $B_{x}$ - importance the orderer attaches to the price criterion

6. $C_{x}$ - index of the percentage of those bidding processes where the winning bid offered the minimal price

\section{Algorithm:}

1. Values of the calculated profit

$Z_{p}=[x+(p-1) z] \%$ for $p=1$ do 6 ,

where $z=(y-x) / 5$

2. Fuzzy relations

$$
\begin{aligned}
& \text { 2.1. } S(O, F) \\
& \quad S\left(O_{j}, F_{n}\right)=S_{j n}=W_{j} \cdot A_{n} \cdot I_{j n} .
\end{aligned}
$$

2.2. $R(F, Z)$

3. Compositions of fuzzy relations

\subsection{Max-min}

$S$ o $R\left(O_{j}, Z_{p}\right)=\max \min \left[S\left(O_{j}, F_{n}\right), R\left(F_{n}, Z_{p}\right)\right]$ for every $F_{n}$.

\subsection{Sum-min}

$S$ o $R\left(O_{j}, Z_{p}\right)=\operatorname{sum} \min \left[S\left(O_{j}, F_{n}\right), R\left(F_{n}, Z_{p}\right)\right]$ for every $F_{n}$.

4. For every $Z_{p}$ the force of recommendation

$$
Q\left(O, Z_{p}\right)=\left[\Sigma Q\left(O_{j}, Z_{p}\right)\right] / \Sigma W_{j} \text { for } j=1 \text { do } 2 .
$$

5. For every $Z_{p}$ the degree of recommendation corrected with respect to the importance the orderer attaches to the price criterion, specified as $Q_{K}\left(Z_{p}\right)$.

6. For every $Z_{p}$ the final degree of recommendation corrected with respect to the index of the percentage of those bidding processes where the winning bid offered the minimal price, specified as $Q_{o}\left(Z_{p}\right)$.

\section{Results:}

1. The max-min rule recommends the following correction of the height of calculated profit:

- calculated profit of $Z_{p}$ height is recommended to $x$ degree, where $p=1$ to $6, x=0 \%$ to $100 \%$.

2. The sum-min rule recommands the following correction of the height of calculated profit:

- calculated profit of $Z_{p}$ height is recommended to $x$ degree, where $p=1$ to $6, x=0 \%$ to $100 \%$. 


\section{Conclusions}

Overheads and profit are a considerable part of cost calculations by the contractor. As it appears from the survey carried out in such countries as Canada or the USA, the overheads are defined and calculated in different ways. It is characteristic that overheads are divided into two separate groups and the ways they are calculated in are also very different. Project overhead costs are usually calculated in detail and company's overhead costs are calculated as an index of an accepted basis. The ways of mark-up defining and calculation are also differentiated.

Legal regulations in effect in Poland since 2001 allow the contractor freedom in shaping overhead costs and profit. The survey results, however, indicate that the majority of the contractors calculate the costs in a traditional, that is index, way. What is worrying is the fact that contractors are unwilling to calculate overhead costs in detail while it is a frequent practice in other countries. In contrast to practices accepted in other countries, profit is understood explicitly and calculated similarly by majority of the contractors. What is positive is the fact that overhead and profit indexes used by Polish contractors are their own ones, more and more often individually adjusted to a particular project. The bases of overhead costs and profit calculations are also to a greater and greater extent differentiated by Polish contractors. It is also worth noticing that some of the contractors try to calculate some mark-ups in detail, e.g. costs connected with subcontractors.

The article presents mathematical methods which can be used by Polish contractors to ensure a precise way of specifying mark-ups. The method specifying overhead costs was created on the basis of neural networks, and the method specifying profit - on the basis of fuzzy sets. The mathematical apparatus in these methods is rather complex, yet if an appropriate software is designed the methods will prove fit to be applied in practice.

\section{References}

Adey, B.; Bruehwiler, E.; Hydan, R. 2004. Effect of common cause failures on indirect costs, Journal of Bridge Engineering ASCE March-April: 200-208. http://dx.doi.org/10.1061/(ASCE)1084-0702(2004)9:2(200)

Apanavičienè, R.; Daugèlienè, A. 2011. New classification of construction companies: overhead costs aspect, Journal of Civil Engineering and Management 17(4): 457-466. http://dx.doi.org/10.3846/13923730.2011.625629

Assaf, S. A.; Bubshait, A. A.; Atiyah, S.; Al-Shahri, M. 2001. The management of construction company overhead costs, International Journal of Project Management 19: 295-303. http://dx.doi.org/10.1016/S0263-7863(00)00011-9

Brauers, W. K. M.; Zavadskas, E. K.; Turskis, Z.; Vilutiené T. 2008. Multi-objective contractor's ranking by applying the MOORA method, Journal of Business Economics and Management 9(4): 245-255. http://dx.doi.org/10.3846/1611-1699.2008.9.245-255

Chua, D. K. H.; Li, D. 2000. Key factors in bid reasoning model, Journal of Construction Engineering and Management ASCE 126(5): 349-357. http://dx.doi.org/10.1061/(ASCE)0733-9364(2000)126:5(349)

Chua, D. K. H.; Li, D.; Chan, W. T. 2001. Case-based reasoning approach in bid decision making, Journal of Construction Engineering and Management ASCE 127(1): 35-45. http://dx.doi.org/10.1061/(ASCE)0733-9364(2001)127:1(35)

Cilensek, R. 1991. Understanding constructor overhead, Cost Engineering AACE 33(12): 21-30. 
Dikmen, I.; Birgonul, M. T.; Gur, A. K. 2007. A case-based decision support tool for bid mark-up estimation of international construction projects, Automation in Construction 17: 30-44. http://dx.doi.org/10.1016/j.autcon.2007.02.009

Dulaimi, M. F.; Hong, G. S. 2002. The factors influencing bid markup decisions of large- and medium-size contractors in Singapore, Construction Management and Economics 20: 601-610. http://dx.doi.org/10.1080/01446190210159890

Egemen, M.; Mohamed, A. 2008. SCBMD: a knowledge-based system software for strategically correct bid/no bid and mark-up size decisions, Automation in Construction ASCE 17: 864-872. http://dx.doi.org/10.1016/j.autcon.2008.02.013

Elazouni, A. M. 2006. Classifying construction contractors using unsupervised-learning neural networks, Journal of Construction Engineering and Management 132(12): 1242-1253. http://dx.doi.org/10.1061/(ASCE)0733-9364(2006)132:12(1242)

Enshassi, A.; Aziz, A. R.; Karriri, A. 2008. Investigating the overhead costs in construction projects in Palestine, Journal of Financial Management of Property and Construction 13(1): 35-47. http://dx.doi.org/10.1108/13664380810882066

Fayek, A. 1998. Competitive bidding strategy model and software system for bid preparation, Journal of Construction Engineering and Management ASCE 124(1): 1-10. http://dx.doi.org/10.1061/(ASCE)0733-9364(1998)124:1(1)

Friedman, L. 1956. A competitive-bidding strategy, Operations Research 4: 104-112. http://dx.doi.org/10.1287/opre.4.1.104

Han, S. H.; Diekmann, J. E. 2001. Making a risk-based bid decision for overseas construction projects, Construction Management and Economics 19: 765-77. http://dx.doi.org/10.1080/01446190110072860

Hegazy, T.; Moselhi, O. 1995. Elements of cost estimation: a survey in Canada and United States, Cost Engineering 37(5): 27-33.

Holland, N. L.; Hobson, D. Jr. 1999. Indirect cost categorization and allocation by construction contractors, Journal of Architectural Engineering 5(2): 49-56. http://dx.doi.org/10.1061/(ASCE)1076-0431(1999)5:2(49)

Hosny, O.; Elhakeem, A. 2012. Simulating the winning bid: a generalized approach for optimum markup estimation, Automation in Construction 22:357-367. http://dx.doi.org/10.1016/j.autcon.2011.09.014

Kapliński, O. 2008. Development and usefulness of planning techniques and decision-making foundations on the example of construction enterprises in Poland, Technological and Economic Development of Economy 14(4): 492-502. http://dx.doi.org/10.3846/1392-8619.2008.14.492-502

Kapliński, O. 2009. Information technology in the development of the Polish construction industry, Technological and Economic Development of Economy 15(3): 437-452. http://dx.doi.org/10.3846/1392-8619.2009.15.437-452

Kosecki, A.; Leśniak, A. 2001. Kalkulacja kosztów pośrednich w opiniach polskich wykonawców budowlanych [Estimating the indirect costs in Polish contractors opinions], in Proceedings of the Scientific Conference of - Technical, technological, organizational and economical aspects of building development, Olsztyn - Łańsk, Poland, 161-169 (in Polish).

Leśniak, A. 2002. Czynniki wpywające na wielkość kosztów pośrednich robót budowlanych [Factors infuensing on overhead costs], Scientific Papers of Silesian University of Technology, Gliwice Poland, 95: 331-338 (in Polish).

Leśniak, A. 2004. Metoda kalkulacji kosztów pośrednich robót budowlanych z zastosowaniem sztucznych sieci neuronowych [Overheads cost calculation by means of artificial neural networks]: PhD Thesis. Cracow University of Technology, Cracow (in Polish).

Li, H.; Love, P. E. D. 1999. Combining rule-based expert systems and artificial neural networks for markup estimation, Construction Management and Economics 17: 169-176.

http://dx.doi.org/10.1080/014461999371664 
Mitkus, S.; Trinkūnienè, E. 2007. Analysis of criteria system model for construction contract evaluation, Technological and Economic Development of Economy 13(3): 244-252.

Mitkus, S.; Trinkūnienè, E. 2008. Reasoned decisions in construction contracts evaluation, Technological and Economic Development of Economy 14(3): 402-416.

http://dx.doi.org/10.3846/1392-8619.2008.14.402-416

Osowski, S. 2000. Sieci neuronowe do przetwarzania informacji [Neural networks for information processing]. Warszawa (in Polish).

Plebankiewicz, E. 2001. Model strategii przetargowej wykonawcy budowlanego z zastosowaniem teorii zbiorów rozmytych [Competitive bidding strategy model by means of fuzzy sets]: $\mathrm{PhD}$ Thesis. Cracow University of Technology, Cracow (in Polish).

Plebankiewicz, E. 2009. Contractor prequalification model using fuzzy sets, Journal of Civil Engineering and Management 15(4): 377-385. http://dx.doi.org/10.3846/1392-3730.2009.15.377-385

Polskie standardy kosztorysowania robót budowlanych [Polish standards of construction works cost estimating]. 2005. Press Society of Polish Cost Estimators, Warsaw (in Polish).

Singh, D.; Tiong, R. L. K. 2005. A fuzzy decision framework for contractor selection, Journal of Construction Engineering and Management ASCE 131(1): 62-70. http://dx.doi.org/10.1061/(ASCE)0733-9364(2005)131:1(62)

Šiškina, A.; Juodis, R.; Apanavičienè. R. 2009. Evaluation of the competitiveness of construction company overhead costs, Journal of Civil Engineering and Management 15(2): 215-224. http://dx.doi.org/10.3846/1392-3730.2009.15.215-224

Skitmore, M. 2004. Predicting the probability of winning sealed bid auctions: the effects of outliers on bidding models, Construction Management and Economics 22: 101-109. http://dx.doi.org/10.1080/0144619042000186103

Skitmore, M.; Drew, D.; Ngai, S. 2001. Bid-spread, Journal of Construction Engineering and Management ASCE 127(2): 149-153. http://dx.doi.org/10.1061/(ASCE)0733-9364(2001)127:2(149)

Tah, J. H. M.; Thorpe, A.; McCaffer, R. 1994. A survey of indirect cost estimating in practice, Construction Management and Economics 12: 31-36. http://dx.doi.org/10.1080/01446199400000004

Tebin, H. I. 2009. Pricing tenders for construction, Cost Engineering 51(1): 7-14.

Turskis, Z. 2008. Multi-attribute contractors ranking method by applying ordering of feasible alternatives of solutions in terms of preferability technique, Technological and Economic Development of Economy 14(2): 224-239. http://dx.doi.org/10.3846/1392-8619.2008.14.224-239

Waara, F.; Brochner, J. 2006. Price and nonprice criteria for contractor selection, Journal of Construction Engineering and Management ASCE 132(8): 797-804.

http://dx.doi.org/10.1061/(ASCE)0733-9364(2006)132:8(797)

Zavadskas, E. K.; Vilutiene, T.; Turskis, Z; Tamošaitienè, J. 2010. Contractor selection for construction works by applying SAW-G and TOPSIS grey techniques, Journal of Business Economics and Management 11(1): 34-55. http://dx.doi.org/10.3846/jbem.2010.03

Zavadskas, E. K.; Turskis, Z.; Tamošaitienė, J. 2008. Contractor selection of construction in a competitive environment, Journal of Business Economics and Management 9(3): 181-187.

http://dx.doi.org/10.3846/1611-1699.2008.9.181-187

Edyta PLEBANKIEWICZ. PhD, Eng, working at Cracow University of Technology, Section of Technology and Building Management. Research interests: organization and modelling of construction processes.

Agnieszka LEŚNIAK. PhD, Eng, working at Cracow University of Technology, Section of Technology and Building Management. Research interests: projects cost estimating, using ANN in construction management, partnering in construction process. 